\title{
Differential effects of selective cyclooxygenase-2 inhibitors in inhibiting proliferation and induction of apoptosis in oral squamous cell carcinoma
}

\author{
SEONG-HEE KO ${ }^{1}$, GEUN JUN CHOI ${ }^{1}$, JI HYE LEE ${ }^{1}$, \\ YOON A HAN ${ }^{1}$, SOO-JEONG LIM ${ }^{2}$ and SO HEE KIM ${ }^{1}$ \\ ${ }^{1}$ College of Dentistry and Research Institute of Oral Science, Kangnung National University, \\ Gangneung-City; ${ }^{2}$ Department of Bioscience and Biotechnology, Sejong University, Seoul, Korea
}

Received September 17, 2007; Accepted November 9, 2007

\begin{abstract}
Cyclooxygenase-2 (COX-2), an enzyme that catalyzes the synthesis of prostaglandins, is made inducible by various stimuli such as inflammation. Although COX-2 is commonly overexpressed in a variety of premalignant and malignant conditions including oral leukoplakia and squamous cell carcinoma, relatively little research has compared the effects of various COX-2 inhibitors (celecoxib, NS-398, nimesulide and meloxicam). Therefore, we investigated the effects of four different selective COX-2 inhibitors on the growth of KB cells, derived from oral squamous cell carcinoma (OSCC) and its mechanisms. Celecoxib and NS-398 strongly suppressed the proliferation of $\mathrm{KB}$ cells at $10-100 \mu \mathrm{M}$, whereas nimesulide and meloxicam are less potent proliferation inhibitors. Only celecoxib induced apoptosis of the KB cells, as detected on the basis of DNA fragmentation, caspase-3/7 activation and cleaved poly(ADP-ribose) polymerase (PARP)
\end{abstract}

Correspondence to: Dr So Hee Kim, College of Dentistry and Research Institute of Oral Science, Kangnung National University, 120 Gangneung Daehangno, Gangneung-City, Gangwon-Do 210-702, Korea

E-mail: shkim67@kangnung.ac.kr

Abbreviations: COX-2, cyclooxygenase-2; OSCC, oral squamous cell carcinoma; PG, prostaglandin; NSAID, non-steroidal antiinflammatory drug; EGFR, epidermal growth factor receptor; PARP, poly(ADP-ribose) polymerase; GAPDH, glyceradehyde-3phosphate dehydrogenase; FBS, fetal bovine serum; PBS, phosphatebuffered saline; $\mathrm{IC}_{50}$, inhibition concentration 50; SDS-PAGE, sodium dodecyl sulfate-polyacrylamide gel; BSA, bovine serum albumin; TBS, Tris-buffered saline; MDR1, multidrug resistance 1; MRP1, multidrug resistance-associated protein 1; BCRP, breast cancer resistance protein; RT-PCR, reverse transcriptionpolymerase chain reaction; PPAR $\gamma$, peroxisome proliferatorsactivated reactor $\gamma$; 4-NQO, 4-nitroquinoline 1-oxide; ABC, ATPbinding cassette

Key words: cyclooxygenase-2 inhibitor, oral squamous cell carcinoma, celecoxib, KB cell, apoptosis, multidrug resistance fragmentation. All four COX-2 inhibitors increased COX-2 protein expression but suppressed prostaglandin (PG) $\mathrm{E}_{2}$ production in the KB cells, suggesting that the pro-apoptotic effect of celecoxib was unrelated to the inhibition of COX-2. Mechanistically, a high level of p53 protein and a low level of multidrug-resistant protein 1 (MRP1) and breast cancer resistant protein (BCRP) mRNA in KB cells with celecoxib may explain the differential effect of these selective COX-2 inhibitors in KB cells. Taken together, celecoxib is a good therapeutic candidate for treating OSCC through the suppression of cell proliferation and the induction of apoptosis in a COX-2 independent manner.

\section{Introduction}

Elevated cyclooxygenase-2 (COX-2) expression occurs in many carcinomas, including oral squamous cell carcinoma (OSCC) and leukoplakia, where it contributes to tumor progression (1). The survival of patients with OSCC has not improved significantly over the past three decades. The main reasons for treatment failure are the development of secondary tumors and an increase in multidrug resistancerelated factors that occur as a result of the chronic exposure of patients with advanced OSCC to various drugs (2). To develop rational therapeutic strategies, it is important to identify molecular targets that are linked to the pathogenesis of OSCC. Currently, COX-2, an inducible enzyme that catalyzes the synthesis of prostaglandins (PG), is being intensively evaluated as a potential molecular target for chemopreventive agents (3).

COXs are rate-limiting enzymes involved in prostanoid production and thromboxane biosynthesis. Two COX isomers exist, $\mathrm{COX}-1$ and -2 , which have been postulated to be target molecules for non-steroidal anti-inflammatory drugs (NSAIDs) (4). COX-1 is a constitutively-expressed housekeeping gene, generally mediating the synthesis of PGs and is required in most tissues for normal physiological functions including the production of a protective mucus by gastrointestinal mucosa and platelet aggregation. In contrast, COX-2 is not detected in many tissues. It is an inducible immediate early gene that has been postulated to be involved not only in inflammation but also in carcinogenesis where it has an 
impact on cell proliferation, differentiation, apoptosis, angiogenesis, metastasis and immunological surveillance $(4,5)$.

NSAIDs have also been shown to exert anti-proliferative and pro-apoptotic effects on a variety of cell lines, particularly colon cancer cell lines $(6,7)$, suggesting a possible mechanism for their chemopreventive action on the colon. Although COX is the molecular target of most NSAIDs, the antiproliferative and pro-apoptotic actions of these drugs have been reported not only to be due to COX-dependent mechanisms $(8,9)$ but also to COX-independent mechanisms (10-12). Accordingly, the mechanism by which NSAIDs inhibit cell proliferation and induce apoptosis remains unclear.

The up-regulated expression of COX-2 in human head and neck squamous cell carcinoma and OSCC has been reported (13). KB cells are derived from OSCC and have a high expression of epidermal growth factor receptors (EGFR), which induce tumors in nude/beige mice (14). Classic NSAIDs inhibit COX-2 and-1, resulting in the common side effect of gastric mucosal damage. To reduce the gastrointestinal side effects of NSAIDs, selective COX-2 inhibitors were developed (15) and the effect of these selective inhibitors on the proliferation and apoptosis of cancer cells has been the subject of much investigation in the past 10 years $(8,11,12)$. However, almost all of these studies have involved the comparison of a COX-2 inhibitor to non-selective NSAIDs (or no comparison at all) in major carcinomas including lung, breast and colon cancers. Thus, relatively little is known about the comparative effects of different selective COX-2 inhibitors on oral cancer cell proliferation and apoptosis. To address this issue, we investigated the effects of four major COX-2 inhibitors (celecoxib, NS-398, nimesulide and meloxicam) on the proliferation and apoptosis of KB cells.

\section{Materials and methods}

Reagents. NS-398 and COX-2 antibody were purchased from Cayman Chemical (Ann Arbor, MI, USA). Meloxicam and nimesulide and the caspase inhibitor N-acetyl-Asp-Glu-ValAsp-aldehyde (Ac-DEVD-CHO) were purchased from Sigma (St. Louis, MO, USA) and Promega (Madison, WI, USA), respectively. Celecoxib was purchased from LKT Laboratories (Minneapolis, MN, USA). Antibodies against poly(ADPribose) polymerase (PARP), p2 $1^{\text {Waf1 }}$ and $\mathrm{p} 27^{\mathrm{Kip} 1}$ antibodies were purchased from Cell Signaling Technology (Beverly, MA, USA). Anti-glyceradehyde-3-phosphate dehydrogenase (GAPDH) and anti-p53 were purchased from Calbiochem (San Diego, CA, USA) and Santa Cruz (Santa Cruz, CA, USA), respectively. Streptavidin-biotin peroxidase was purchased from DAKO (Cambridge, UK). NS-398, nimesulide, meloxicam and celecoxib were dissolved in dimethyl sulfoxide (Sigma) and the final concentration of the vehicle in all cultures was $0.1 \%$.

Human KB cell culture. KB cells were obtained from the American Type Culture Collection (ATCC, Rockville, MD, USA) and cultured in Dulbecco's modified Eagle's medium (Invitrogen, Carlsbad, CA, USA), supplemented with 10\% fetal bovine serum (FBS, Invitrogen), $100 \mathrm{U} / \mathrm{ml}$ of penicillin (Invitrogen) and $100 \mu \mathrm{g} / \mathrm{ml}$ of streptomycin (Invitrogen). The cells were maintained in a humidified environment of $5 \%$
$\mathrm{CO}_{2} / 95 \%$ air at $37^{\circ} \mathrm{C}$. The cells were cultured in $60 \mathrm{~mm}^{2}$ tissue culture dishes and grown to $80 \%$ confluency before use.

Immunocytochemical assessment of $\mathrm{COX}-2$. For immunocytochemical COX-2 analysis of the KB cells, the streptavidinbiotin-peroxidase complex method was employed. Cells were treated with $3 \% \mathrm{H}_{2} \mathrm{O}_{2}$ for $30 \mathrm{~min}$ to eliminate the cellular intrinsic peroxidase activity and incubated with a primary antibody against COX-2 (Cayman) (1:100 dilution in phosphate-buffered saline, PBS) for $16 \mathrm{~h}$ at $4^{\circ} \mathrm{C}$. Cells were then washed twice with PBS and treated with streptavidinbiotin-peroxidase (DAKO) before being detected with 3,3'diaminobenzidine $\mathrm{HCl}$. The expression of COX-2 was visualized by microscopy (magnification, x100).

Cell proliferation assay. To test the effect of selective COX-2 inhibitors on cell proliferation, cells were plated into flatbottomed 24 -well plates and the density $\left(1-2 \times 10^{4}\right.$ cells/well in $1 \mathrm{ml}$ medium) was determined on the basis of the growth characteristics. After overnight incubation, triplicate wells were treated with varying concentrations of drugs for 24,48 and $72 \mathrm{~h}$. The relative percentage of metabolically-active cells to untreated controls was then determined on the basis of the mitochondrial conversion of 3-(4,5-dimethylthiazol-2-yl)2,5-diphenyltetrazolium bromide to formazine. The ability of cells to form formazine, by active mitochondrial respiration, was detected using a 96-well format plate reader and the absorbance was measured at a wavelength of $550 \mathrm{~nm}\left(\mathrm{~A}_{550 \mathrm{~nm}}\right)$. The percentage of metabolically-active cells was compared to the percentage of control cells growing in the absence of drugs in the same culture plate. The percentage of inhibition was calculated using the formula: $\%$ inhibition $=\left(1-\mathrm{OD}_{\text {test }} t\right.$ $\mathrm{OD}_{\text {control }}$ ) x $100 . \mathrm{IC}_{50} \mathrm{~s}$ (inhibition concentration 50) were calculated by plotting the log of the percentage of inhibition values versus the drug concentrations (16).

DNA fragmentation assay. The KB cells $\left(1 \times 10^{4} /\right.$ well) were treated with the test drugs during culture for $24 \mathrm{~h}$ in $96-$ well plates containing a medium with $1 \%(\mathrm{v} / \mathrm{v}) \mathrm{FBS}$. Cytoplasmic DNA fragments, which are an indicator of apoptosis, were measured with a DNA cell death detection ELISA ${ }^{\text {PLUS }}$ kit (Roche Diagnostics GmbH, Mannheim, Germany) according to the manufacturer's instructions.

Assay of caspase-3/7 activity. The KB cells (1x104/well) were treated with the test drugs in 96-well plates containing a medium with $1 \%$ (v/v) FBS for $6 \mathrm{~h}$. The level of caspase-3/7 activity, in the cells, was then measured by an Apo-ONE ${ }^{\mathrm{TM}}$ homogeneous caspase-3/7 assay (Promega) according to the manufacturer's instructions.

Assay of $\mathrm{PGE}_{2}$ production. The $\mathrm{KB}$ cells $\left(5 \times 10^{5} /\right.$ well) were pretreated with the test drugs in 24-well plates containing a medium with $1 \%(\mathrm{v} / \mathrm{v})$ FBS for $1 \mathrm{~h}$. The media was then removed and the cells were washed with $\mathrm{PBS}$ buffer. Arachidonic acid (10 $\mu \mathrm{M}$, Sigma) was added to the serumfree media and the cells were incubated for another hour. The $\mathrm{PGE}_{2}$ level in the culture medium was then measured using a commercial ELISA kit (Cayman) according to the manufacturer's instructions. 
A

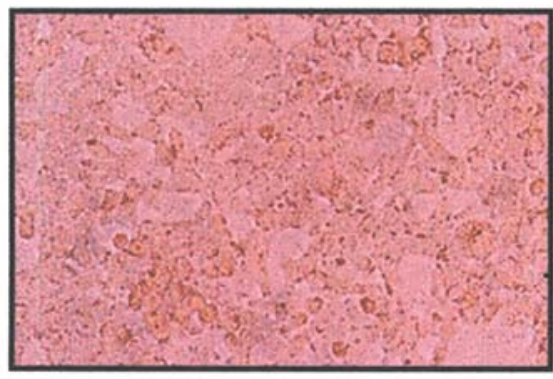

B

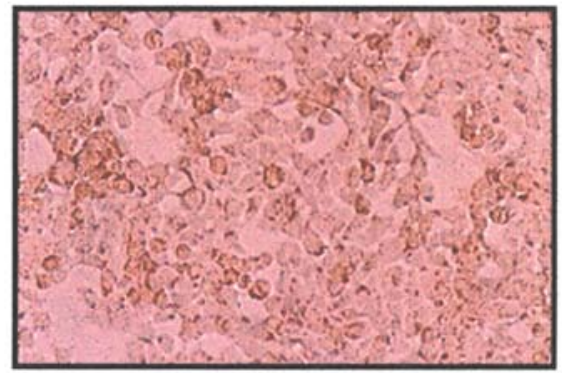

Figure 1. Cyclooxygenase-2 (COX-2) expression in KB cells. (A) Vehicle-treated KB cells (control, x100). (B) COX-2 antibody-treated KB cells (x100).

Immunoblot analysis. For immunoblot analysis, the cells were lysed in buffer consisting of $50 \mathrm{mM}$ HEPES ( $\mathrm{pH} 7.2$ ), $150 \mathrm{mM} \mathrm{NaCl}, 1.5 \mathrm{mM} \mathrm{MgCl}_{2}, 1 \mathrm{mM}$ EGTA, $10 \%$ glycerol, $1 \%$ Triton $\mathrm{X}-100,10 \mathrm{mM}$ sodium pyrophosphate, $1 \mathrm{mM}$ sodium orthovanadate, $1 \mathrm{mM} \mathrm{MnCl}{ }_{2}, 10 \mu \mathrm{g} / \mathrm{ml}$ leupeptin and $2 \mathrm{mM}$ phenylmethylsulfonyl fluoride. Protein concentrations were determined using the BCA protein assay (Sigma). GAPDH (Calbiochem) was used as an internal standard for the normalization of protein loading of the immunoblots.

Protein samples (20-40 $\mu \mathrm{g}$ protein/lane) from cells were resolved by electrophoresis on a $10 \%$ sodium dodecyl sulfatepolyacrylamide gel (SDS-PAGE) and transferred to a nitrocellulose membrane (Pall Corporation, Ann Arbor, MI, USA). For immunodetection, blots were incubated overnight with the appropriate diluted primary antibody in 5\% bovine serum albumin (BSA), Tris-buffered saline (TBS) and $0.1 \%$ Tween-20 at $4^{\circ} \mathrm{C}$ with gentle shaking. Immunoblots were then incubated with secondary antibody conjugated to horseradish peroxidase (diluted 1:10.000). The protein expression was detected by enhanced chemiluminescence (Amersham Life Science, Piscataway, NJ, USA) on Kodak X-OMAT film (Sigma). Exposed film was scanned and the bands were quantified using Kodak 1D image analysis (Eastman Kodak Company, Rochester, NY, USA) equipped with an analysis software program.

MRP1, MDR1 and BCRP expression. Total cellular RNA was isolated from KB cells using a Trizol reagent (Invitrogen) and purified with an RNeasy mini kit (Qiagen, Santa Clarita, CA, USA) according to the manufacturer's instructions. Single-stranded oligo(dT)-primed cDNA was generated from $2 \mu \mathrm{g}$ of total RNA in a $25 \mathrm{ml}$ reaction mixture using Moloney murine leukemia virus reverse transcriptase (Promega). Primers used for the analysis of human multidrug resistance 1 (MDR1), multidrug resistance-associated protein 1 (MRP1) and breast cancer resistance protein (BCRP) were: MRP1 (sense primer 5'-CGTGTACTCCAACGCTGAC-3' and antisense primer 5'-CTGGACGCCTGACGCCC-3', 325 bp), MDR1 (sense primer 5'-GGAAGCCAATGCCTATGAC TTTA-3' and antisense primer 5'-GAACCACTGCTTCGCT TTCTG-3', 193 bp) and BCRP (sense primer 5'-TGGCTGTC ATGGCTTCAGTA-3' and antisense primer 5'-GCCACGT GATTCTTCCACAA-3', 205 bp) and GAPDH was used as an internal standard (sense primer 5'-GTCAACGGATTT GGTCGTATT-3' and antisense primer 5'-AGTCTTCTGGG
TGGCAGTGAT-3'). The amplification reaction was carried out with $2 \mu 1$ of cDNA product for 27 cycles and each cycle consisted of $94^{\circ} \mathrm{C}$ for $45 \mathrm{sec}, 57^{\circ} \mathrm{C}$ for $50 \mathrm{sec}$ and $72^{\circ} \mathrm{C}$ for $50 \mathrm{sec}$, followed by a final 1 -min elongation at $72^{\circ} \mathrm{C}$. The final polymerase chain reaction (PCR) products were electrophoresed on a $1 \%$ agarose gel.

Statistical analysis. Statistically significant differences $(\mathrm{p}<0.05)$ between the control and each treated group were determined by a two tailed unpaired Student's t-test.

\section{Results}

Immunocytochemical assessment of $C O X-2$. To confirm the expression of COX-2 in the KB cells, immunocytochemical analysis was carried out using the streptavidin-biotinperoxidase complex method. COX-2 staining was not detected in vehicle-treated control KB cells (Fig. 1A) but was strongly positive in $\mathrm{KB}$ cells incubated with primary antibody against COX-2 (Fig. 1B). Immunoblot analysis for COX-2 also showed a strong COX-2 protein expression in $\mathrm{KB}$ cells (data not shown).

The effect of $\mathrm{COX}-2$ inhibitors on cell proliferation. After confirming the expression of COX-2 in the $\mathrm{KB}$ cells, we examined the effect of four selective COX-2 inhibitors on the proliferation of $\mathrm{KB}$ cells by measuring the mitochondrial conversion of 3-(4,5-dimethylthiazol-2-yl)-2,5-diphenyltetrazolium bromide to formazine (Fig. 2). The KB cells were incubated with each of the inhibitors for 24,48 and $72 \mathrm{~h}$ at various concentration ranges $(0-100 \mu \mathrm{M}$ for celecoxib and NS-398, and 0-1000 $\mu \mathrm{M}$ for nimesulide and meloxicam, respectively). The KB cell proliferation was strongly inhibited by the four selective COX-2 inhibitors studied, in a dose- and time-dependent manner (Fig. 2A). The inhibition of KB cell proliferation was most potent following incubation with the inhibitor for $72 \mathrm{~h}$ and potency decreased progressively at 48 and $24 \mathrm{~h}$ treatment at time points (Fig. 2A). The potency for the inhibition of cell proliferation at $100 \mu \mathrm{M}$ for $72 \mathrm{~h}$ was 93.4, 55.3, 43.3 and 21.1\% inhibition for celecoxib, NS-398, nimesulide and meloxicam (Fig. 2B), respectively. These results suggest that celecoxib is the strongest suppressor of $\mathrm{KB}$ cell proliferation. The $\mathrm{IC}_{50}$ values for the 72-h treatment were $34.6,64.7,136$ and $386 \mu \mathrm{M}$ for celecoxib, NS-398, nimesulide and meloxicam, respectively. Again, our results 

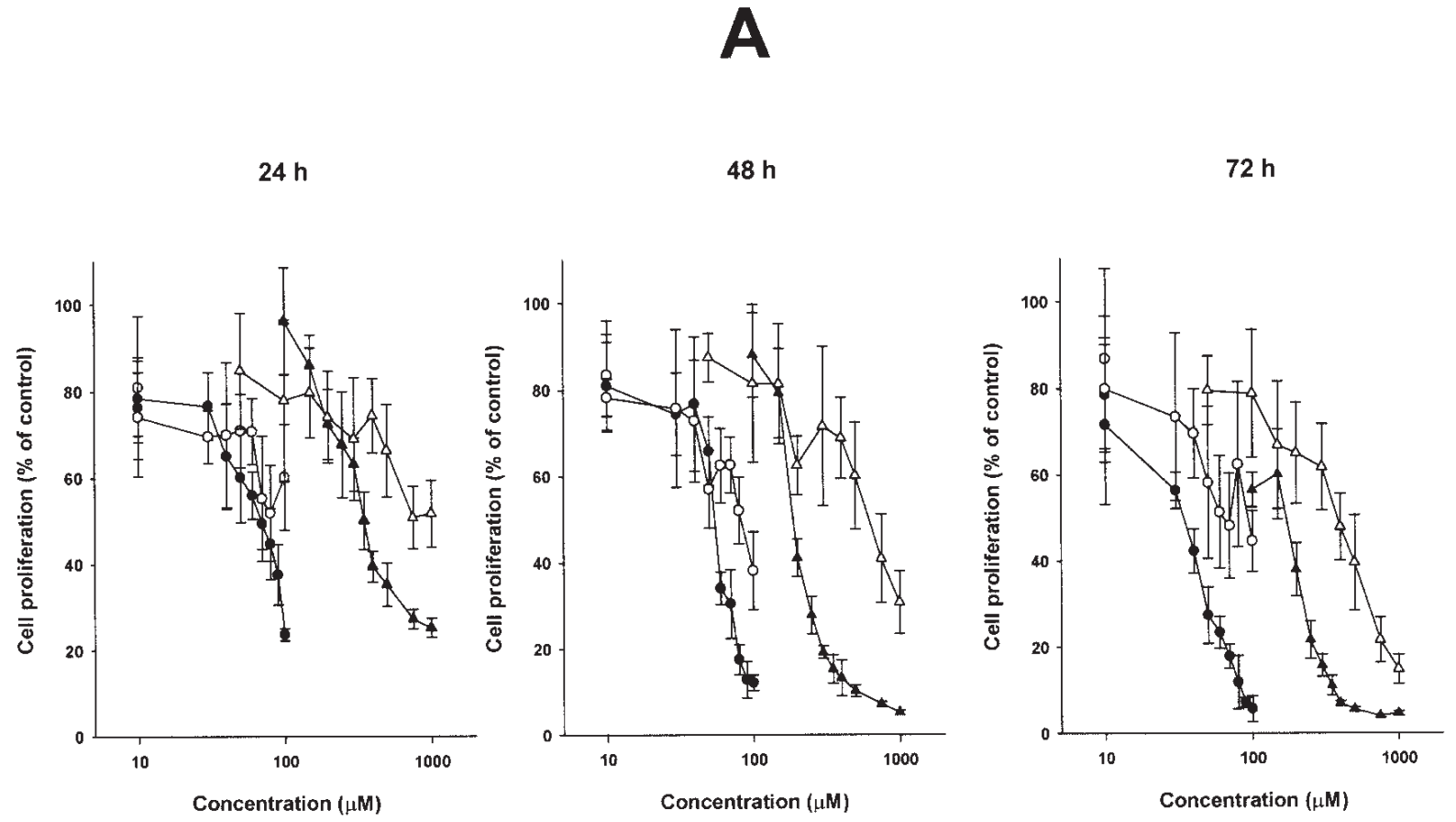

B

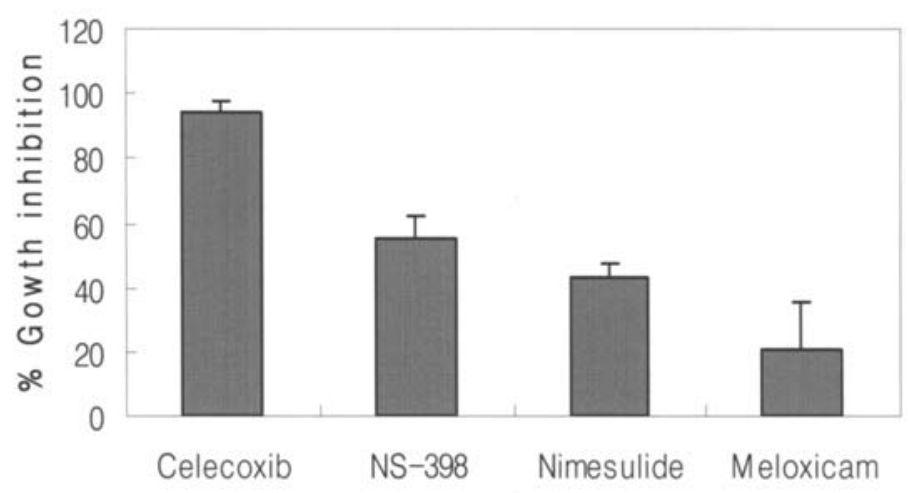

Figure 2. Effects of various COX-2 inhibitors on the proliferation of KB cells. (A) The cells were treated with celecoxib $(\bullet)$, NS-398 $(\bigcirc)$, nimesulide ( $\mathbf{\wedge})$ and meloxicam $(\triangle)$ for 24,48 and $72 \mathrm{~h}$. Cell proliferation was estimated by mitochondrial conversion of 3-(4,5-dimethylthiazol-2-yl)-2,5-diphenyltetrazolium bromide to formazine and is presented as a percentage of the control value. (B) KB cells were treated with celecoxib, NS-398, nimesulide and meloxicam at $100 \mu \mathrm{M}$ for $72 \mathrm{~h}$. Cell proliferation was estimated as in (A) and is presented as \% growth inhibition as described in Materials and methods. Data are mean \pm SD of triplicate cultures. The representative results of three independent experiments are shown.

indicate that of the four selective COX-2 inhibitors studied, $\mathrm{KB}$ cells were most sensitive to celecoxib.

The effect of $\mathrm{COX}-2$ inhibitors on apoptosis. To determine whether the suppression of KB cell proliferation by COX-2 inhibitors is due to the induction of apoptosis, the appearance of DNA fragmentation (a hallmark of apoptosis) was quantitatively analyzed by ELISA after incubation with each inhibitor. This method specifically detects cytoplasmic histone-associated DNA fragments, mononucleosomes and oligonucleosomes. As shown in Fig. 3A, DNA fragmentation was detectable after a 4-h incubation period with $50 \mu \mathrm{M}$ of celecoxib. After $24 \mathrm{~h}$, DNA fragmentation increased. Following exposure to the $100 \mu \mathrm{M}$ celecoxib, the DNA fragments were released into the culture medium, indicating that the cells had undergone a secondary necrosis, which usually occurs after apoptosis (Fig. 3B). In contrast, NS-398, nimesulide or meloxicam, which also inhibited cell proliferation, did not influence DNA fragmentation at concentrations of up to $200 \mu \mathrm{M}$ and after incubation for 4 or $24 \mathrm{~h}$.

The effect of COX-2 inhibitors on caspase-3/7 activation. Caspases are responsible for many of the biochemical and morphological changes that occur during apoptosis. We therefore investigated whether selective COX-2 inhibitors induce the activation of caspase-3 and/or -7 (caspase-3/7) in $\mathrm{KB}$ cells. As shown in Fig. 4, the incubation of KB cells with $50 \mu \mathrm{M}$ celecoxib for $6 \mathrm{~h}$ induced the activation of caspase- $3 / 7$ and this activation was completely blocked by the incubation 
$4 \mathrm{~h}$

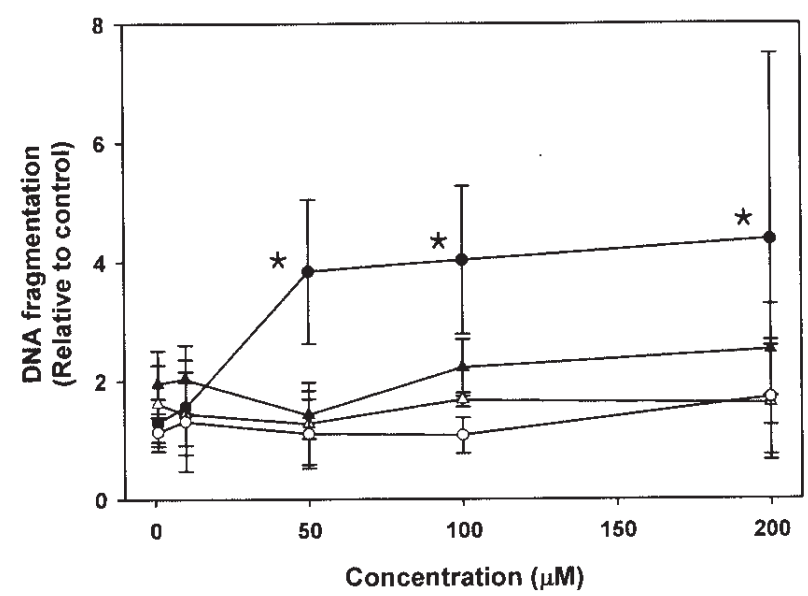

$24 \mathrm{~h}$

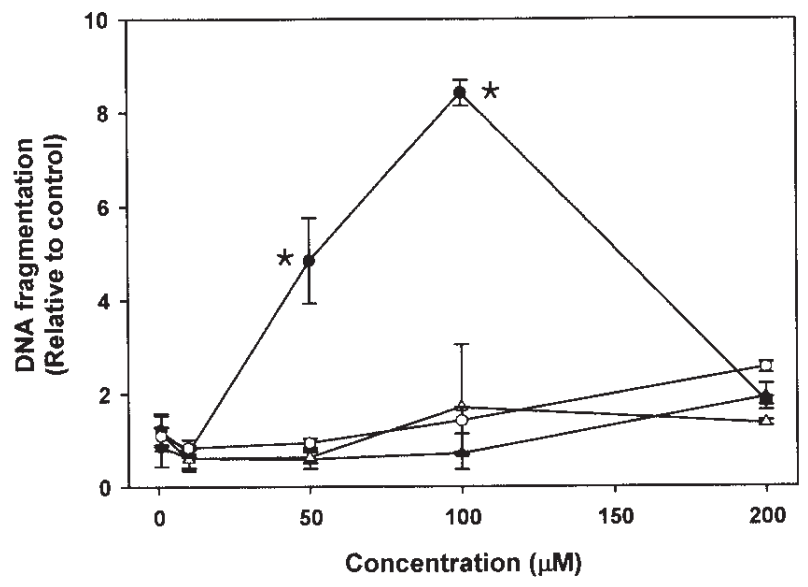

Figure 3. Effects of various COX-2 inhibitors on DNA fragmentation in KB cells. The cells were treated with celecoxib $(\bullet)$, NS-398 $(\bigcirc)$, nimesulide $(\mathbf{\Delta})$ and meloxicam $(\triangle)$ for $4(\mathrm{~A})$ and $24 \mathrm{~h}(\mathrm{~B})$. The level of DNA fragmentation in the cytoplasm was measured by ELISA. The fold induction of DNA fragmentation is shown relative to the value for the control. Data are mean \pm SD of the triplicate cultures. The representative results of three independent experiments are shown; ${ }^{*} \mathrm{p}<0.01$ compared to the control.

Caspase 3 Activity

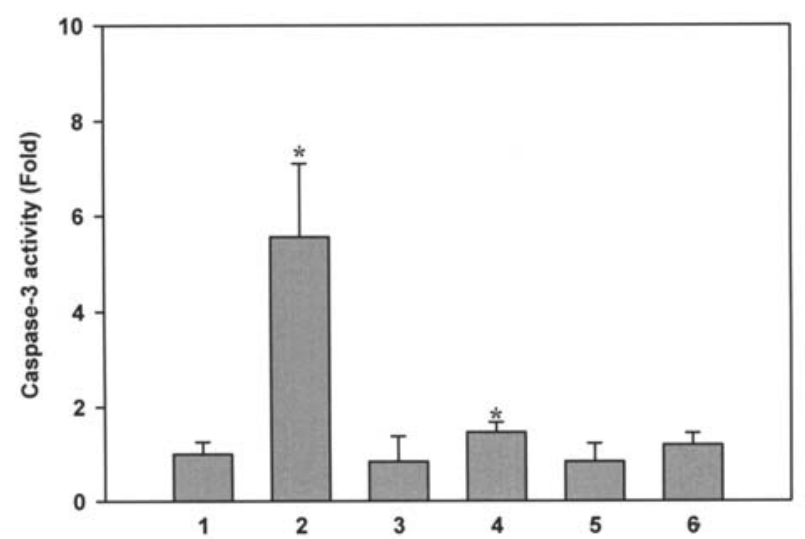

Figure 4. Effects of various COX-2 inhibitors on the caspase-3/7 activation in $\mathrm{KB}$ cells. The cells were cultured without COX-2 inhibitors (1) or incubated with $50 \mu \mathrm{M}$ celecoxib (2), $50 \mu \mathrm{M}$ celecoxib $+10 \mu \mathrm{M}$ Ac-DEVD-CHO (3), $50 \mu \mathrm{M}$ NS-398 (4), $200 \mu \mathrm{M}$ nimesulide (5) and $200 \mu \mathrm{M}$ meloxicam (6) for $6 \mathrm{~h}$ and then caspase activity was measured by the Apo-ONE ${ }^{\mathrm{TM}}$ homogeneous caspase-3/7 assay kit. The fold changes of the caspase-3/7 activity are shown relative to the value for the control. Data are the mean \pm SD of triplicate cultures. The representative results of two independent experiments are shown; ${ }^{*} \mathrm{p}<0.05$ compared to the control.

with the caspase inhibitor Ac-DEVD-CHO. In contrast, the other selective COX-2 inhibitors (50 or $200 \mu \mathrm{M}$ ) did not alter the basal level of caspase-3/7 activity in KB cells (Fig. 4).

The effect of COX-2 inhibitors on $\mathrm{PGE}_{2}$ production. To examine the effect of COX-2 inhibitors on the production of $\mathrm{PGE}_{2}$ by $\mathrm{KB}$ cells, the cells were treated with $\mathrm{COX}-2$ inhibitors for $1 \mathrm{~h}$ and/or stimulated with $10 \mu \mathrm{M}$ of arachidonic acid for another hour. As shown in Fig. 5, a concentration range of 0.5 to $50 \mu \mathrm{M}$ of all COX-2 inhibitors studied suppressed $\mathrm{PGE}_{2}$ production with (Fig. 5A) or without arachidonic acid (Fig. 5B) in a concentration-dependent (celecoxib and NS-398) or concentration-independent (nimesulide and meloxicam) manner. Selective COX-2 inhibitors with arachidonic acid suppressed $\mathrm{PGE}_{2}$ production more potently.

The effect of $\mathrm{COX}-2$ inhibitors on protein expression. To examine the effect of COX-2 inhibitors on the COX-2 protein expression, KB cells were treated with selective COX-2 inhibitors for $24 \mathrm{~h}$ and immunoblot analysis was performed. As shown in Fig. 6A, the protein level of COX-2 expression increased considerably by $1.51,1.63,2.00$ and 1.79 times, compared to the control for NS-398, meloxicam, celecoxib and nimesulide, respectively. These data suggest that the effects of COX-2 inhibitors on cell proliferation or apoptosis are independent of the COX-2 protein expression.

We also analyzed the cleavage of PARP, one of the main cleavage targets of caspase-3 in vivo (17). As shown in Fig. 6A, the cleaved PARP fragment increased 3.3-fold in $50 \mu \mathrm{M}$ celecoxib-treated cells, indicating that PARP cleavage is consistent with an increased caspase-3/7 activity and DNA fragmentation in celecoxib-treated $\mathrm{KB}$ cells. To determine whether the effect of selective COX-2 inhibitors on KB cell proliferation is a result of cell cycle inhibition, we analyzed the cyclin-dependent kinase inhibitors, p21 ${ }^{\text {Waf1 }}, \mathrm{p} 27^{\mathrm{Kip} 1}$ and $\mathrm{p} 53$ using immunoblot analysis. As shown in Fig. 6B, the p $21^{\text {Waf1 }}$ and $\mathrm{p} 27^{\mathrm{Kip} 1}$ protein expression increased significantly by 60 and $89 \%$, respectively, in cells treated with nimesulide. Similarly, the p53 protein expression increased significantly by $98 \%$ in celecoxib-treated cells but little change was observed when the cells were treated with other selective COX-2 inhibitors.

MRPI and BCRP expression. To investigate whether selective COX-2 inhibitors can modulate the function of multidrug-resistance related factors, we assayed the MRP1, MDR1 and BCRP mRNA expression in KB cells using reverse transcription (RT)- PCR. MRP1 and BCRP mRNA were highly expressed but the expression of MDR1 mRNA 

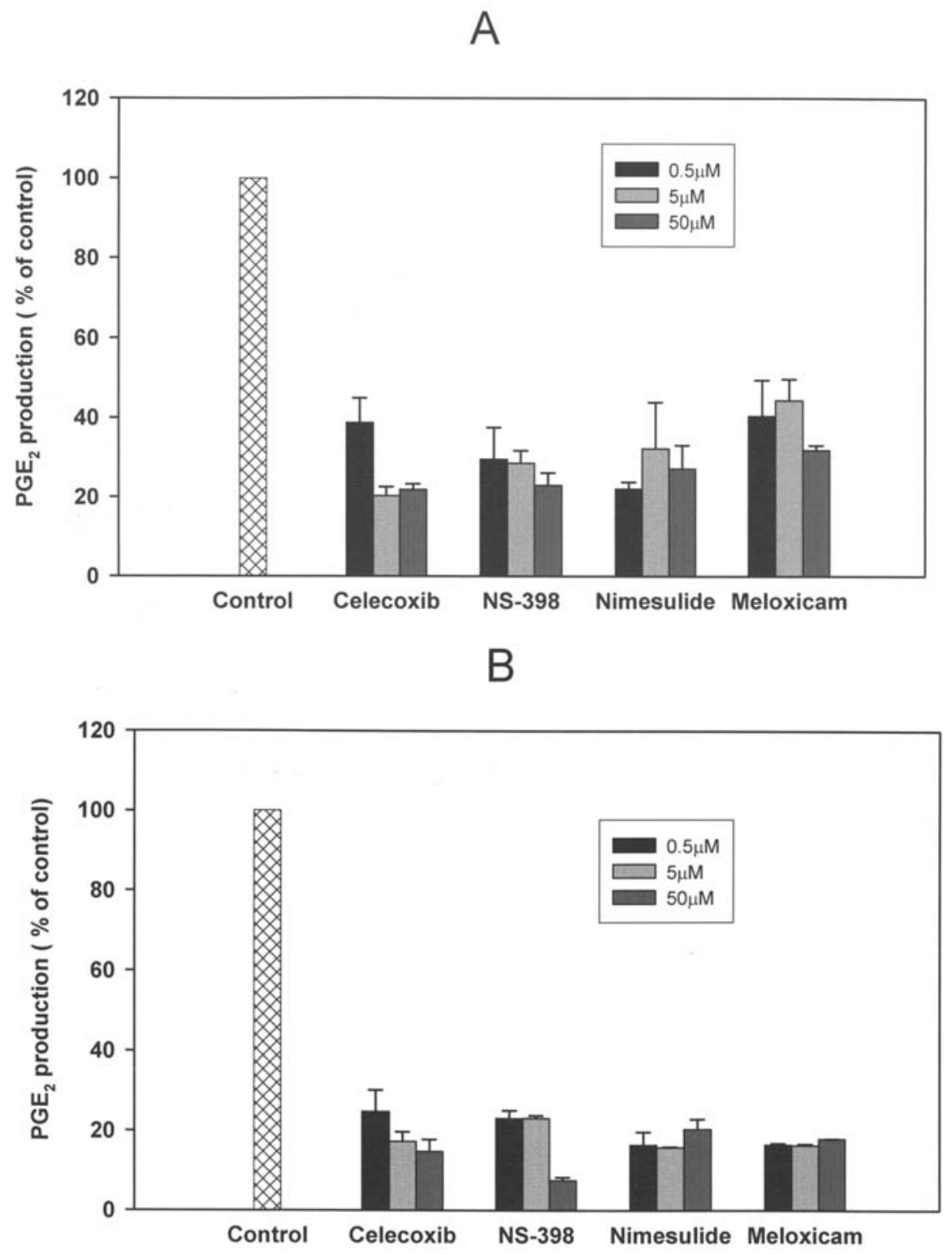

Figure 5. Effects of various COX-2 inhibitors on $\mathrm{PGE}_{2}$ production by KB cells. (A) The cells were incubated with the selective COX-2 inhibitors for $1 \mathrm{~h}$ at $37^{\circ} \mathrm{C}$. After incubation, the $\mathrm{PGE}_{2}$ level was measured in the culture medium by enzyme immunoassay. Data are the mean $\pm \mathrm{SD}$ of duplicate cultures. The $\mathrm{PGE}_{2}$ level in the control culture medium was $1.12 \pm 0.116 \mathrm{ng} / \mathrm{ml}$. (B) The cells were preincubated with the selective COX-2 inhibitors for $1 \mathrm{~h}$ at $37^{\circ} \mathrm{C}$ and then $10 \mu \mathrm{M}$ arachidonic acid was added. After incubation for another hour, the $\mathrm{PGE}_{2}$ level was measured in the culture medium by enzyme immunoassay. Data are the mean $\pm \mathrm{SD}$ of duplicate cultures. The $\mathrm{PGE}_{2}$ level of the control culture medium was $2.50 \pm 0.204 \mathrm{ng} / \mathrm{ml}$. The representative results of three independent experiments are shown.

was not detected in KB cells (Fig. 7). In our study, celecoxib down-regulated the expression of MRP1 and BCRP mRNA by 32 and $21 \%$, respectively (Fig. 7). These data support the notion that the down-regulation of MRP1 and BCRP mRNA, by celecoxib, may decrease the efflux of drugs, increase the intracellular concentration of celecoxib and thus inhibit cell proliferation and induce apoptosis more effectively than the other selective COX-2 inhibitors we studied.

\section{Discussion}

In this study, we evaluated the effects and mechanisms of four major selective COX-2 inhibitors (celecoxib, NS-398, nimesulide and meloxicam) on the proliferation and apoptosis of KB cells. We clearly showed that celecoxib and NS-398 can strongly suppress cell proliferation at the same concentration ranges $(10-100 \mu \mathrm{M})$. However, nimesulide and meloxicam are less potent $\mathrm{KB}$ cell proliferation inhibitors since a 10 times higher concentration range $(100-1000 \mu \mathrm{M})$ is required for the inhibition of proliferation. Among these four COX-2 inhibitors, only celecoxib induced the characteristic features of apoptosis, including DNA fragmentation, caspase-3/7 activation and cleaved PARP fragmentation in the KB cells. It has been reported that NS-398 also induces the apoptosis of colon (18), lung (19) and breast (20) carcinoma cells in vitro. In the present study, however, no such pro-apoptotic effect was observed, although NS-398 did inhibit cell proliferation. This discrepancy may be explained 
A

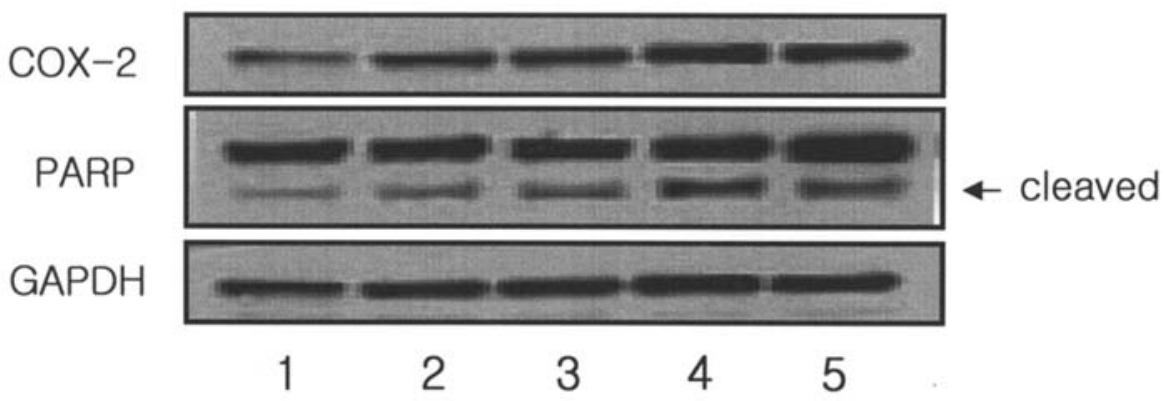

cox-2

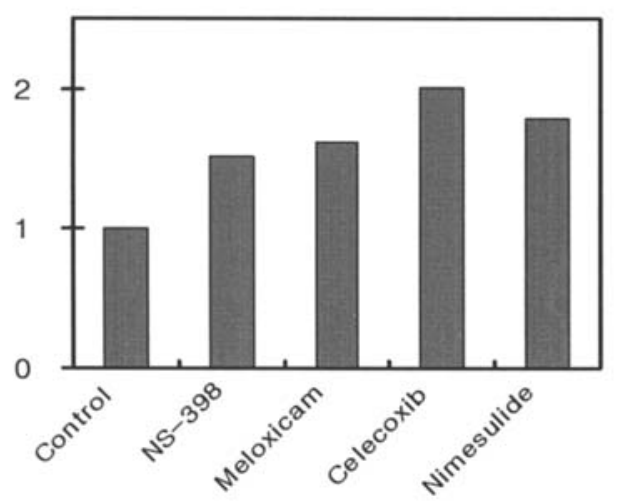

Cleaved PARP

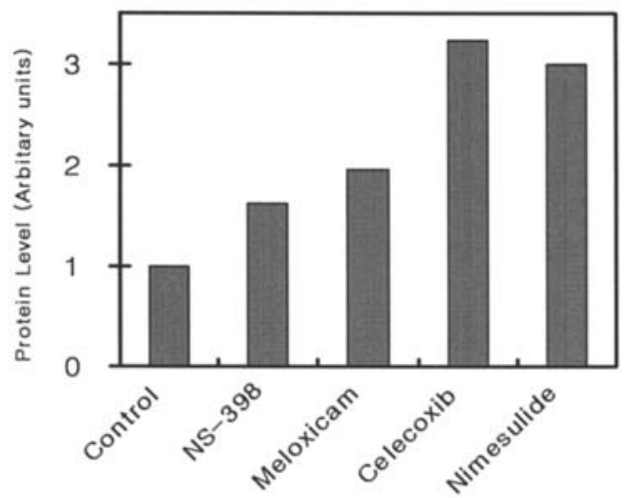

B
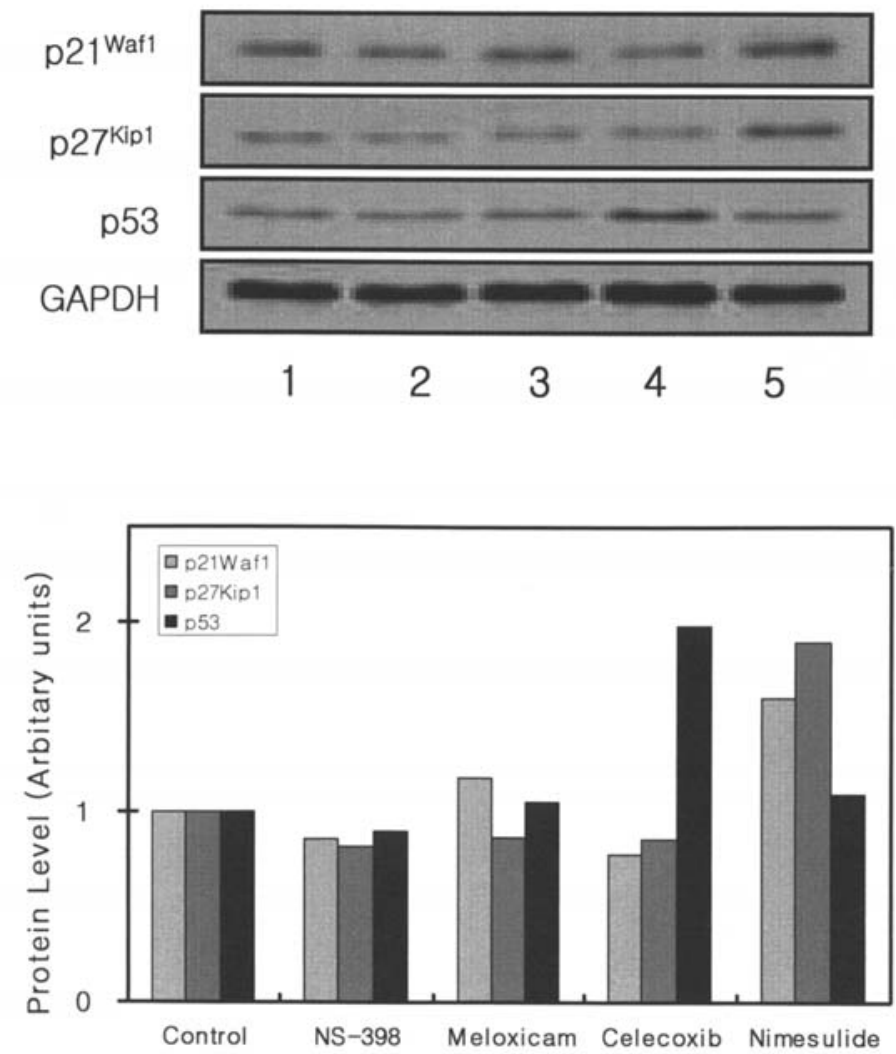

Figure 6. Effects of selective COX-2 inhibitors on protein expression in KB cells. The cells were cultured without COX-2 inhibitors (1) or incubated with $50 \mu \mathrm{M}$ NS-398 (2), $100 \mu \mathrm{M}$ meloxicam (3), $50 \mu \mathrm{M}$ celecoxib (4) and $100 \mu \mathrm{M}$ nimesulide (5) for $24 \mathrm{~h}$. Protein extracts were prepared from the cells and subjected to immunoblotting, as described in Materials and methods. (A) represents the COX-2, PARP and cleaved PARP protein expression as an immunoblot (top) and graphically (bottom). (B) shows the protein expression of $\mathrm{p} 21^{\text {Wafl }}, \mathrm{p} 27^{\mathrm{Kip} 1}$ and $\mathrm{p} 53$ as an immunoblot (top) and graphically (bottom). 


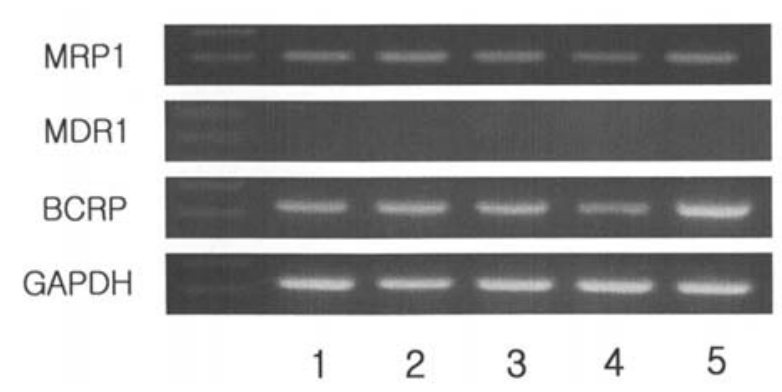

Figure 7. Effects of selective COX-2 inhibitors on the expression of MDR1, MRP1 and BCRP mRNA in KB cells. The cells were cultured without COX-2 inhibitors (1) or incubated with $50 \mu \mathrm{M}$ NS-398 (2), $100 \mu \mathrm{M}$ meloxicam (3), $50 \mu \mathrm{M}$ celecoxib (4) and $100 \mu \mathrm{M}$ nimesulide (5) for $24 \mathrm{~h}$. The expression of MDR1, MRP1 and BCRP mRNA was determined in KB cells by semi-quantitative RT-PCR, with GAPDH mRNA serving as a loading control.

by differences in the carcinoma cells and the culture conditions. In the previous studies, apoptosis was determined after a relatively long culture period (more than 2 days) when compared with our study (4-24 h). In contrast, we found that celecoxib induces apoptosis after only $4 \mathrm{~h}$. Taken together, these results indicate that the pro-apoptotic mechanism of celecoxib may be different from that of other selective COX-2 inhibitors.

$\mathrm{KB}$ cells have served as a useful model for examining the mechanisms by which NSAIDs reduce the proliferation of OSCC because the KB cells express COX-2 protein and mRNA. Although all four selective COX-2 inhibitors studied here share the ability to inhibit $\mathrm{PGE}_{2}$ production by $\mathrm{KB}$ cells, these inhibitors show a differential suppression of cell proliferation and induction of apoptosis. In addition, much higher doses of these four selective COX-2 inhibitors are required to achieve inhibition of cell growth than to inhibit $\mathrm{PGE}_{2}$ production. However, there seems to be little doubt that $\mathrm{COX}-2$ contributes to tumorigenesis in OSCC, because all four COX-2 inhibitors [celecoxib (21), NS-398 (1), nimesulide (22) and meloxicam (23)] show an anti-tumor effect in animal models including those of chemically-induced carcinogenesis. These findings, combined with the present observations, suggest that the inhibition of cell proliferation and induction of apoptosis do not fully explain the mechanism by which selective COX-2 inhibitors exert an anti-tumor activity in vivo. It is possible that indirect mechanisms, such as an anti-angiogenetic action (24), suppression of tumor invasion and down-regulation of matrix metalloproteinase-2 $(1,25)$, may be more important than the direct effects of such agents on OSCC in vivo.

It is also possible that certain selective COX-2 inhibitors induce apoptosis of OSCC via targets that are not necessarily related to the COX-2 inhibitory activity. In this respect, the observation that certain NSAIDs act as a direct ligand for peroxisome proliferator-activated receptor $\gamma(\operatorname{PPAR} \gamma)$ is of interest (26). We found that various NSAIDs, such as indomethacin, diclofenac, oxaprozin and zaltoprofen, induce apoptosis of rheumatoid synovial fibroblasts in association with PPAR $\gamma$ activation (26). Studies have also indicated that PPAR $\gamma$ is expressed in OSCC, including KB cells and 4nitroquinoline 1-oxide (4-NQO)-induced oral carcinoma tissue. Dietary troglitazone, a selective PPAR $\gamma$ ligand, inhibits 4-NQO-induced tongue carcinogenesis and suppresses an increased cell proliferation and/or COX-2 expression (27). However, we found that all four selective COX-2 inhibitors showed little change in the PPAR $\gamma$ mRNA expression and did not induce a transcriptional activation of PPAR $\gamma$ in a luciferase reporter assay (data not shown).

PARP is important for cells to maintain their viability. The cleavage of PARP facilitates cellular disassembly and serves as a marker of cells undergoing apoptosis (28). In our study, cleaved PARP fragmentation was evident in celecoxibtreated cells and was followed by the induction of apoptosis in response to caspase- 3 activation. These results were further confirmed by the finding that the p53 protein expression increased in celecoxib-treated $\mathrm{KB}$ cells, which may contribute to the inhibition of cell growth and induction of apoptosis. We also confirmed that nimesulide increased the expression of $\mathrm{p} 21^{\text {Waf1 }}$ and $\mathrm{p} 27^{\mathrm{Kip} 1}$ proteins in $\mathrm{KB}$ cells and thus inhibited $\mathrm{KB}$ cell growth. It has been reported that celecoxib also inhibits the $G_{0} / G_{1}$ to $S$ phase transition by decreasing the expression of cyclins and increasing the expression of cyclin-dependent kinase inhibitory proteins, such as p21 Waf1 and p27 Kip1, in colon cancer cells (29). Recently, celecoxib was shown to induce the translation of p27 ${ }^{\mathrm{Kip} 1}$ mRNA, which triggers the inhibition of cell growth via $\mathrm{p} 27^{\mathrm{Kip} 1}$-regulated cell cycle arrest in human OSCC and YD-10B cells (30).

It has not been confirmed whether celecoxib is a substrate for multidrug resistance-related factors. The multidrug resistance-related factors MRP1, BCRP and/or MDR1 are transporter proteins belonging to the ATP-binding cassette (ABC) superfamily. However, our data demonstrate that celecoxib reverses BCRP- and MRP1-related drug resistance via the down-regulation of MRP1 and BCRP mRNA. Thus, it is plausible that the efflux of celecoxib is decreased and the intracellular concentration of the drug is increased, and while not measured here, this may contribute to the increase in drug sensitivity. This may therefore be another indirect mechanism by which celecoxib inhibits cell proliferation and induces apoptosis more effectively. Recent reports have shown a multitargeted inhibition of drug-resistant multiple myeloma cell lines by an analog of celecoxib known as dimethyl-celecoxib (31) and have also shown an inhibitory effect of celecoxib combined with or without octreotide on the growth of a multidrug resistant human gastric cancer cell line SGC7901/ADR (32).

In summary, celecoxib strongly suppresses the proliferation of KB cells and induces their apoptosis, as detected by DNA fragmentation, caspase-3/7 activation and cleaved PARP fragmentation in a COX-2-independent manner. These data also confirm that celecoxib-treated KB cells express high levels of the p53 protein and low levels of MRP1 and BCRP mRNA. Accordingly, celecoxib is a good therapeutic candidate for treating human OSCC in a COX-2 independent manner.

\section{Acknowledgements}

This work was supported by a research grant (RTI 05-01-02) from the Regional Technology Innovation Program of the Ministry of Commerce, Industry and Energy (MOCIE). 


\section{References}

1. Nystrom ML, McCulloch D, Weinreb PH, Violette SM, Speight PM, Marshall JF, Hart IR and Thomas GJ: Cyclooxygenase-2 inhibition suppresses alphavbeta6 integrindependent oral squamous carcinoma invasion. Cancer Res 66: 10833-10842, 2006.

2. Day GL and Blot WJ: Second primary tumors in patients with oral cancer. Cancer 70: 14-19, 1992.

3. Dannenberg AJ, Altorki NK, Boyle JO, Dang C, Howe LR, Weksler BB and Subbaramaiah K: Cyclooxygenase-2: a pharmacological target for the prevention of cancer. Lancet Oncol 2: 544-551, 2001

4. Shiff SJ and Rigas B: Nonsteroidal anti-inflammatory drugs and colorectal cancer: evolving concepts of their chemopreventive actions. Gastroenterology 113: 1992-1998, 1997.

5. Williams CS, Mann M and DuBois RN: The role of cyclooxygenases in inflammation, cancer, and development. Oncogene 18: 7908-7916, 1999.

6. Piazza GA, Rahm AL, Krutzsch M, Sperl G, Paranka NS Gross PH, Brendel K, Burt RW, Alberts DS, Pamukcu R and Ahnen DJ: Antineoplastic drugs sulindac sulfide and sulfone inhibit cell growth by inducing apoptosis. Cancer Res 55: 3110-3116, 1995.

7. Shiff SJ, Koutsos MI, Qiao L and Rigas B: Nonsteroidal antiinflammatory drugs inhibit the proliferation of colon adenocarcinoma cell effects on cell cycle and apoptosis. Exp Cell Res 222: 179-188, 1996.

8. Sheng H, Shao J, Kirkland SC, Isakson P, Coffey RJ, Morrow J, Beauchamp RD and DuBois RN: Inhibition of human colon cancer cell growth by selective inhibition of cyclooxygenase-2. J Clin Invest 99: 2254-2259, 1997.

9. Souza RF, Sheqmake K, Beer DG, Cryer B and Spechler SJ: Selective inhibition of cyclooxygenase-2 suppresses growth and induces apoptosis in human esophageal adenocarcinoma cells. Cancer Res 60: 5767-5772, 2000.

10. Hanif R, Pittas A, Feng Y, Koutsos MI, Qiao L, Staiano-Coico L, Shiff SI and Rigas B: Effects of nonsteroidal anti-inflammatory drugs on proliferation and on induction of apoptosis in colon cancer cells by a prostaglandin-independent pathway. Biochem Pharmacol 25: 237-245, 1996.

11. Elder DJ, Halton DE, Hague A and Paraskeva C: Induction of apoptotic cell death in human colorectal carcinoma cell lines by a cyclooxygenase-2 (COX-2)-selective nonsteroidal antiinflammatory drug: independence from $\mathrm{COX}-2$ protein expression. Clin Cancer Res 3: 1679-1683, 1997.

12 Smith ML, Hawcroft C and Hull MA: The effect of nonsteroidal anti-inflammatory drugs on human colorectal cancer cells: evidence of different mechanisms of action. Eur J Cancer 36: 664-674, 2000

13. Chan G, Boyle JO, Yang EK, Zhang F, Sacks PG, Shah JP, Edelstein D, Soslow RA, Koki AT, Woemer BM, Masferrer JL and Dannenberg AJ: Cyclooxygenase-2 expression is upregulated in squamous cell carcinoma of the head and neck. Cancer Res 59: 991-994, 1999.

14. Nicolini G, Miloso M, Moroni MC, Beguinot L and Scotto L: Post-transcriptional control regulates transforming growth factor alpha in the human carcinoma KB cell line. J Biol Chem 271: 30290-30296, 1996.

15. Jackson LM and Hawkey CJ: COX-2 selective nonsteroidal anti-inflammatory drugs: do they really offer any advantages? Drugs 59: 1207-1216, 2000 .

16. Waskewich C, Blumenthal RD, Li H, Stein R, Goldenberg DM and Burton J: Celecoxib exhibits the greatest amongst cyclooxygenase (COX) inhibitors for growth inhibition of COX-2-negative hematopoietic and epithelial cell lines. Cancer Res 62: 2029-2033, 2002.

17. Tewari M, Quan LT, L'Rourke K, Desnovers S, Zeng Z, Beidler DR, Poirier GG, Salvesen GS and Dixit VM: Yama/CPP32 beta, a mammalian homolog of CED-3, is a CrmA-inhibitable protease that cleaves the death substrate poly(ADP-ribose) polymerase. Cell 81: 801-809, 1995.
18. Smartt HJ, Elder DJ, Hicks DJ, Williams NA and Paraskeva C: Increased NF-kappaB DNA binding but not transcriptional activity during apoptosis induced by the $\mathrm{COX}$-2-selective inhibitor NS-398 in colorectal carcinoma cells. Br J Cancer 89: 1358-1365, 2003.

19. Han S and Roman J: COX-2 inhibitors suppress lung cancer cell growth by inducing p21 via COX-2 independent signals. Lung Cancer 51: 283-296, 2006.

20. Simeone AM, Li YJ, Broemeling LD, Johnson MM, Tuna M and Tari AM: Cyclooxygenase- 2 is essential for HER2/neu to suppress $\mathrm{N}$-(4-hydroxyphenyl) retinamide apoptotic effects in breast cancer cells. Cancer Res 64: 1224-1228, 2004.

21. Nishimura N, Urade M, Hashitani S, Noguchi K, Manno Y, Takaoka $\mathrm{K}$ and Sakurai K: Increased expression of cyclooxygenase (COX)-2 in DMBA-induced hamster cheek pouch carcinogenesis and chemopreventive effect of a selective COX-2 inhibitor celecoxib. J Oral Pathol Med 33: 614-621, 2004.

22. Shiotani H, Denda A, Yamamoto K, Kitayama W, Endoh T, Sasaki Y, Tsutsumi M, Sugimura M and Konishi Y: Increased expression of cyclooxygenase-2 protein in 4-nitroquinoline-1oxide-induced rat tongue carcinomas and chemopreventive efficacy of a specific inhibitor, nimesulide. Cancer Res 61: 1451-1456, 2001.

23. Naruse T, Nishida Y, Hosono K and Ishiguro N: Meloxicam inhibits osteosarcoma growth, invasiveness and metastasis by COX-2-dependent and independent routes. Carcinogenesis 27: 584-592, 2006.

24. Wang Z, Fuentes CF and Shapshay SM: Antiangiogenic and chemopreventive activities of celecoxib in oral carcinoma cell. Laryngoscope 112: 839-843, 2002.

25. Kinugasa $Y$, Hatori M, Ito H, Kurihara $Y$, Ito D and Nagumo M: Inhibition of cyclooxygenase-2 suppresses invasiveness of oral squamous cell carcinoma cell lines via down-regulation of matrix metalloproteinase-2 and CD44. Clin Exp Metastasis 21: 737-745, 2004

26. Yamazaki R, Kusunoki N, Matsuzaki T, Hashmoto S and Kawai S: Nonsteroidal anti-inflammatory drugs induce apoptosis in association with activation of peroxisome proliferators-activated receptor $\gamma$ in rheumatoid synovial cells. J Pharmacol Exp Ther 302: 18-25, 2002.

27. Yoshida K, Hirose Y, Tanaka T, Yamada Y, Kuno T, Kohno H, Katayama M, Qiao Z, Sakata K, Sugie S, Shibata T and Mori H: Inhibitory effects of troglitazone, a peroxisome proliferatorsactivated receptor gamma ligand, in rat tongue carcinogenesis initiated with 4-nitroquinoline 1-oxide. Cancer Sci 94: 365-371, 2003.

28. Oliver FJ, de la Rubia G, Rolli V, Ruiz-Ruiz MC, de Murcia G and Murcia JM: Importance of poly(ADP-ribose) polymerase and its cleavage in apoptosis. Lesson from an uncleavable mutant. J Biol Chem 273: 33533-33539, 1998.

29. Grösch S, Tegeder I, Niederberger E, Bräutigam L and Geisslinger G: COX-2 independent induction of cell cycle arrest and apoptosis in colon cancer cells by the selective COX-2 inhibitor celecoxib. FASEB J 15: 2742-2744, 2001.

30. Lee EJ, Kim SH, Kwark YE and Kim J: Heterogeneous nuclear ribonuclear protein $\mathrm{C}$ is increased in the celecoxib-induced growth inhibition of human oral squamous cell carcinoma. Exp Mol Med 38: 203-209, 2006.

31. Kardosh A, Soriano N, Liu YT, Uddin J, Petasis NA, Hofman FM, Chen TC and Schonthal AH: Multitarget inhibition of drugresistant multiple myeloma cell lines by dimethyl-celecoxib (DMC), a non-COX-2 inhibitory analog of celecoxib. Blood 106: 4330-4338, 2005.

32. Zheng WB, Wang $\mathrm{CH}$, Qiang $\mathrm{O}$ and Tang $\mathrm{CW}$ : Inhibitory effects of celecoxib combined with octreotide on growth of multidrug resistant human gastric cancer cell line SGC7901/ADR. Ai Zheng 23: 1628-1632, 2004. 